\begin{tabular}{|c|c|c|c|} 
Dinamika Journal, Vol. 1 No.3, 2019 \\
ISSN ONLINE : 2686-2158
\end{tabular}

\title{
PENERAPAN BUDIDAYA PADI DENGAN METODE SRI (SISTEM OF RICE INTENSIFICATION) DI DESA PATEMON KECAMATAN BOJONGSARI KABUPATEN PURBALINGGA
}

\author{
Okti Herliana*, Sapto Nugroho Hadi, Wilis Cahyani \\ Jurusan Agroteknologi, Fakultas Pertanian, Universitas Jenderal Soedirman \\ Jl. Dr. Soeparno No.61 Karangwangkal Purwokerto Jawa Tengah, 53123 \\ Corresponding author: okti.herliana@unsoed.ac.id \\ Received 2019; Accepted 2019; Available online 2019
}

\begin{abstract}
Abstrak
Desa Patemon terletak di wilayah Kecamatan Bojongsari, Kabupaten Purbalingga, lebih kurang $17 \mathrm{Km}$ dari Kampus Universitas Jenderal Soedirman dengan jumlah Kepala Keluarga 528 dan jumlah penduduk 4350 orang. Mata pencaharian penduduk kebanyakan sebagai petani. Potensi pertanian Desa Patemon Kecamatan Bojongsari meliputi: padi, jagung, kedelai dan singkong. Luas lahan sawah di desa ini mencapai 128.000 ha namun sayang produktivitasnya masih tergolong rendah. Hal ini dikarenakan petani masih melaksanakan sistem budidaya secara konvensional dan kurangnya pengetahuan mengenai pengelolaan tanaman terpadu. Kegiatan ini bertujuan untuk memberikan pengetahuan dan contoh cara bertaman padi alternatif, yaitu bertanam padi dengan metode SRI (System of Rice Intensification) dengan aplikasi pupuk kompos jerami dan pestisida nabati. Kegiatan ini melibatkan khalayak sasasaran yaitu Kelompok tani "Warakan Tani" di Desa Patemon Kecamatan Bojongsari dan penyuluh pertanian di kecamatan Bojongsari. Metode yang digunakan dalam kegiatan ini yaitu: 1. Kegiatan penyuluhan langsung kepada kelompok tani 2. Praktek langsung / Demplot budidaya tanaman padi dengan metode SRI (System of Rice Intensification) atau pembuatan demplot. Rancangan Evaluasi yang dilakukan berupa pemberian pretes sebelum kegiatan penyuluhan dimulai dan postes sesudah kegiatan penyuluhan dimulai, hal ini dimaksudkan untuk mengetahui sejauh mana pemahaman petani mengenai metode SRI.
\end{abstract}

Kat kunci : SRI, Padi, Kelompok Tani

\begin{abstract}
Patemon Village is located in the District of Bojongsari, Purbalingga Regency, approximately $17 \mathrm{Km}$ from the General Soedirman University Campus with a total of 528 Family Heads and a population of 4350 people. The livelihoods of the population are mostly farmers. Agricultural potential of Patemon Village, Bojongsari Subdistrict includes: rice, corn, soybeans and cassava. The area of paddy fields in this village reaches 128,000 ha but unfortunately its productivity is still relatively low. This is because farmers are still implementing conventional cultivation systems and lack of knowledge about integrated crop
\end{abstract}


management. This activity aims to provide knowledge and examples of alternative rice cultivation methods, namely rice farming using the SRI (System of Rice Intensification) method with the application of straw compost and vegetable pesticides. This activity involved the target audience, namely the "Warakan Tani" farmer group in Patemon Village, Bojongsari District and agricultural instructors in Bojongsari sub-district. The methods used in this activity are: 1. Direct extension activities to farmer groups 2. Direct practice / rice cultivation demonstration plot using SRI (System of Rice Intensification) method or making demonstration plots. The evaluation design is in the form of providing pre-test before the extension activity begins and post-test after the extension activity begins, this is intended to determine the extent of farmers' understanding of the SRI method.

Keywords: rice, SRI, farmer community

\section{PENDAHULUAN}

Pertanian padi di Desa Patemon Kecamatan Bojongsari Kabupaten Purbalingga sebagian besar berada pada lahan sawah yang beririgasi semi teknis dan sebagian lainnya tanah hujan. Menurut Rialisasi (2013) Luas lahan sawah di desa ini mencapai 128.000 ha, luas tegalan 46.000, luas pekarangan 28.676 ha jadi total luas tanah darat yang berpotensi dimanfaatkan untuk budidaya tanaman 74.676 ha. Namun demikian, umumnya, para petani memiliki luas lahan sawah yang terbatas, yaitu antara $2000 \mathrm{~m}^{2}$ sampai $10000 \mathrm{~m}^{2}$. Bahkan, ada juga sebagian petani yang sama sekali tidak memiliki lahan sendiri. Pada umumnya petani padi ini menggunakan sawah sewaan, dengan sistem sewa $2: 1$ (dua bagian panen untuk petani dan satu bagian untuk pemilik sawah dan 1 bagian untuk petani penggarap). Produktivitas sawah di desa ini juga masih tergolong rendah. Rata-rata hasil padi per-hektar per-musim tanam sekitar $4-5$ ton. Produktivitas seperti ini telah berlangsung sangat lama tanpa ada kemungkinan peningkatan. Peningkatan produktivitas padi di daerah ini akan sangat sulit terjadi apabila tidak ada inovasi baru.

Cara bercocok tanam padi dengan metode SRI (System of Rice Intensification) pertama kali dikembangkan di Madagascar 20 tahun yang lalu oleh Fr. Henri de Laulanié, S.J., yang menghabiskan waktu selama 34 tahun bekerja bersama petani, mengamati, bereksperimen, dan juga mendapatkan 'keberuntungan' pada tahun 1983-1984. Metoda ini dikenal juga dengan nama Metoda Madagascar. Pada tahun 1994 Tefy Saina (lembaga swadaya masyarakat) dan CIIFAD (Cornel International Institute for Food and Agriculture Development) mulai bekerjasama dalam pengembangan SRI. Dengan bantuan CIIFAD khususnya dari Prof. Norman Uphoff, SRI menyebar ke negara lain (Barkelaar, 2001).

Di Indonesia sendiri, uji coba pola/teknik SRI pertama dilaksanakan oleh Lembaga Penelitian dan Pengembangan Pertanian di Sukamandi Jawa Barat pada musim kemarau 1999 dengan hasil 6,2 ton/ha dan pada musim hujan 1999/2000 menghasilkan padi rata-rata 8,2 ton/ha (Uphoff, 2002; Sato, 2007). SRI juga telah diterapkan di beberapa kabupaten di Jawa, Sumatera, Bali, Nusa Tenggara Barat dan Nusa Tenggara Timur yang sebagian besar dipromosikan oleh Lembaga Swadaya Masyarakat (Wardana et al., 2005).

Selanjutnya, SRI juga telah berkembang di beberapa daerah di Sulawesi, Kalimantan bahkan rencana pengembangan di Irian (Papua). Sementara itu di Jawa Barat pola pendekatan SRI pertama kali dikaji di Kelompok Studi Petani (KSP) Tirta Bumi di Desa Budi Asih Kecamatan Cikoneng, Kabupaten Ciamis pada tahun 2001, dengan memadukan praktek pemahaman Pembelajaran Ekologi Tanah (PET) (Kuswara, 2003).

Berdasarkan hasil observasi di lapangan mengindikasikan bahwa ada beberapa penyebab mengapa produktivitas padi di daerah ini sulit meningkat. Salah satu penyebab

Dinamika Journal Vol. 1 No. 3, Oktober 2019 : 40 - 51 
adalah petani tidak mempunyai keberanian dan pengetahuan untuk mengusahakan dengan cara baru. Ada kesan bahwa cara menanam padi tidak bisa diubah sebagaimana yang dilakukan saat ini. Pendapat bahwa padi harus ditanam dalam air melekat kuat dipikiran para petani. Masalah lain adalah pupuk yang dipakai pada tanaman padi. Hampir semua petani di desa ini menganggap bahwa padi hanya memerlukan pupuk urea.

Kondisi ini tentu tidak menguntungkan. Produktivitas sawah di daerah ini menjadi statis dan rendah. Petani tidak dapat meningkatkan pendapatannya sehingga tidak ada perbaikan kesejahteraan. Petani miskin menjadi tetap miskin. Kegiatan Pengabdian Masyarakat ini menawarkan satu solusi untuk meningkatkan produktivitas padi di desa Patemon dengan teknik budidaya Padi dengan Metode SRI.

\section{METODE PELAKSANAAN}

Metode yang dilaksanakan dalam kegiatan Pengabdian Kepada Masyarakat program penerapan iptek ini adalah:

\section{a. Lokasi, waktu pelaksanaan dan khalayak sasaran}

Kegiatan pengabdian masyarakat penerapan ipteks dilaksanakan di Desa Patemon Kecamatan Bojongsari Kabupaten Purbalingga, pada bulan Maret sampai Oktober 2015. Dengan khalayak sasaran adalah kelompok tani "Warakan Tani”"

\section{b. Kegiatan penyuluhan dan pendampingan}

Kegiatan alih teknologi budidaya padi Metode SRI diawali dengan pretest untuk mengukur tingkat pemahaman petani sebelum diadakan ssosialisasi dan penyuluhan. Sosialisasi dilakukan dalam bentuk SL-PTT (Sekolah Lapang Pengelolaan Tanaman Terpadu). Hal ini dimaksudkan untuk mempercepat proses adopsi inovasi teknologi dikalangan petani padi sawah.

\section{c. Pembuatan Demplot}

Pembuatan demplot dimaksudkan untuk menerapkan secara langsung alih teknologi yang sebelumnya sudah dipraktekkan. Petak percobaan yang digunakan seluas $5000 \mathrm{~m}^{2}$. Penyuluhan dan bimbingan pelaksanaan metode SRI secara rinci langsung diperagakan di demplot tersebut. Garis besar kegiatan teknik budi daya tanaman padi metode SRI adalah sebagai berikut:

1. Penanaman bibit muda (8-12 hari setelah berkecambah)

2. Jarak tanam yang lebar (minimal $25 \mathrm{~cm} \times 25 \mathrm{~cm}, 1$ bibit per titik)

3. Menghindari trauma pada bibit saat penanaman

4. Penanaman padi secara dangkal

5. Manajemen Air (Pengairan macak-macak)

6. Meningkatkan aerasi tanah dengan pembajakan mekanis

7. Menjaga keseimbangan biologi tanah (Penggunaan Pupuk dan Pestisida Organik).

\section{d. Evaluasi Kegiatan dan keberlanjutan program}

Evaluasi dilakukan dalam bentuk monitoring (pemantauan) yang dilaksanakan selama kegiatan dilakukan. Perubahan pengetahuan dievaluasi dengan pre-test dan post-test. Kegiatan yang dilakukan berupa monitoring secara berkala terhadap aktivitas yang dilakukan selama demplot oleh angota kelompok tani "Warakan". 
Seluruh anggota kelompok tani "Warakan" terlebih dahulu dievaluasi (pre-test) untuk mengetahui tingkat pengetahuan dan pemahaman budidaya padi Metode SRI, pembuatan pupuk kompos jerami padi dan pengelolaan hama penyakit terpadu. Kemudian dilanjutkan dengan praktek dan demplot. Kriteria keberhasilan penyerapan pengetahuan dievaluasi dengan kriteria sebagai berikut :
a). $20-40 \%=$ materi kegiatan tidak dapat diserap
b). $41-60 \%=$ materi kegiatan cukup terserap
c). $61-100 \%=$ materi kegiatan terserap dengan baik

Kriteria keberhasilan peningkatan pengetahuan dan pemahaman anggota kelompok tani warakan diukur dengan indikator sebagai berikut:

a) $\quad 70 \%$ kelompok sasaran memahami budidaya padi dengan metode SRI dengan aplikasi triko kompos jerami padai dan pestisida nabati = sangat baik

b) $60-70 \%$ kelompok sasaran memahami budidaya padi dengan metode SRI dengan aplikasi triko kompos jerami padai dan pestisida nabati = baik

c) 40-59\% kelompok sasaran memahami budidaya padi dengan metode SRI dengan aplikasi triko kompos jerami padi dan pestisida nabati $=$ sedang

d) $\quad<40 \%$ kelompok sasaran memahami budidaya padi dengan metode SRI dengan aplikasi triko kompos jerami padai dan pestisida nabati = kurang

Kriteria keberhasilan penerapan anggota kelompok tani warakan terhadap budidaya padi Metode SRI diukur dengan indikator sebagai berikut:

a). 20-40 \% anggota kelompok tani warakan akan melakukan penanaman = cukup berhasil

b). 41-60 \% anggota kelompok tani warakan akan melakukan penanaman = berhasil

c). 61-100\% anggota kelompok tani warakan akan melakukan penanaman = sangat berhasil

Keberlanjutan program pengabdian penerapan ipteks ini adalah secara berkala melakukan monitoring dan kunjungan ke lapangan untuk mendampingi petani jika menemukan kendala dilapangan terkait pelaalih teknologi SRI yang sudah di berikan, bekerjasama dengan penyuluh pertanian setempat untuk ikut melakukan pendampingan supaya kelompok tani konsisten menerapkan metode SRI dalam budidaya padu nya.

\section{HASIL DAN PEMBAHASAN}

Padi merupakan kebutuhan utama bagi masyarakat Indonesia, karena sebagai sumber energi dan karbohidrat bagi mereka. Selain itu, padi juga merupakan tanaman yang paling penting bagi jutaan petani kecil yang ada di berbagai wilayah di Indonesia. Kebutuhan pangan terus meningkat seiring bertambahnya jumlah penduduk (Handono, 2013) Peningkatan produksi padi menjadi tanggung jawab bersama antara, petani, penyulih, akademisi dan pemerintah selaku pemangku kebijakan. Introduksi budidaya padi Metode SRI (System Rice of Intensification) diharapkan menjadi salah satu alternatif cara meningkatkan produksi padi yang ramah lingkungan dan berkelanjutan. Kegiatan pengabdian masyarakat penerapan ipteks ini dilaksanakan oleh tim dari Jurusan Agroteknologi Fakultas Pertanian Universitas Jenderal Soedirman, dengan tahapan kegiatan sebagai berikut:

\section{Sosialisasi kegiatan dan Penyuluhan Teknik Budidaya SRI}

Penyuluhan yaitu untuk memberikan informasi tentang metode SRI, efektifitas trikoderma sebagai stater pembuatan kompos, dan pengendalian hama penyakit tanaman padi menggunakan pestisida nabati. Kegiatan ini dilaksanakan di Balai Desa Patemon pada tanggal 3 Mei 2015 yang dihadiri oleh sekitar 25 orang anggota kelompok tani "Warakan", 
Adapun materi penyuluhan adalah 1). Teknis budidaya padi metode SRI 2). Budidaya padi metode SRI menggunkan pupuk triko kompos jerami padi. 3) Pembuatan MOL (Mikro organismo lokal dan pestisida nabati sebagai bahan pengendalian hama penyakit tanaman secara terpadu. kegiatan penyuluhan dan pelatihan ditampilkan pada gambar 1-3 sebagai berikut:
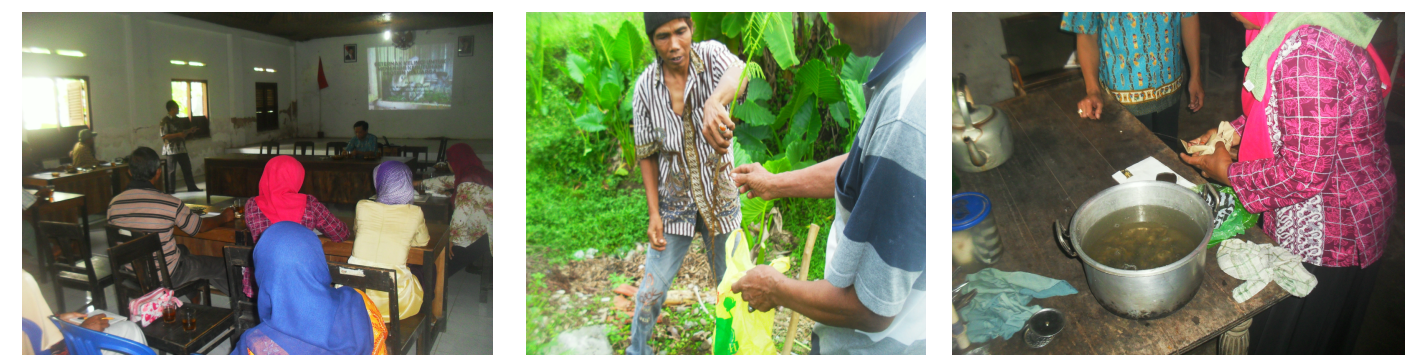

Gambar 1. Suasana penyuluhan budiaya padi metode SRI

Gambar 2. Pengambilan bakteri pada perakaran pohon putri malu (Mimosa púdica)

Gambar 3. Perebusan keongmas dan terasi sebagai stater agensia hayati

Kegiatan penyuluhan dan praktek dilaksanakan melalui SL-PTT (Sekolah Lapang Pengelolaan Tanaman Terpadu). Materi diberikan dengan cara ceramah dan dilanjutkan dengan diskusi oleh tim pengabdi. Hasil pree test dan post test terhadap 25 orang anggota kelompok Tani Warakan menunjukkan terdapat peningkatan pemahaman dan ketrampilan terkait materi yang sudah diberikan dalam kegiatan penyuluhan.

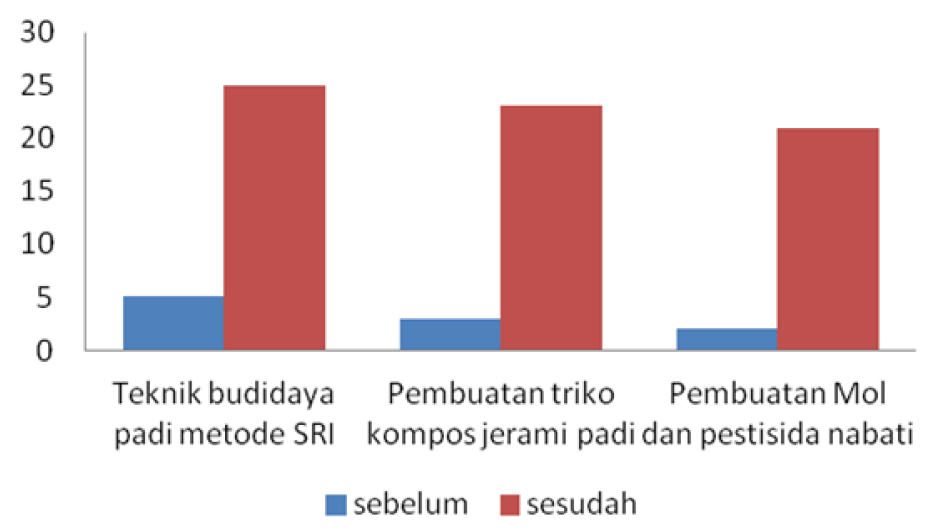

Grafik 1. Peningkatan pemahaman dan ketrampilan petani terhadap materi yang diberikan.

Data menunjukkan bahwa pada saat awal kegiatan sebanyak 5 dari 25 orang baru memahami budidaya SRI setelah dilaksanakan penyuluhan dan pelatihan meningkat menjadi 23 orang yang paham dan meninkat ketrampilannya. Peningkatan pembuatan triko kompos jerami padi sebelum kegiatan hanya 3 orang yang memahami setelah dilakukan penyululah dan pelatihan meningkat menjadi 23 orang dan pada kegiatan penyuluhan dan praktek pembuatan MOL dan biopestisida sebagai pengendalian hama penyakit semula hanya 2 yang memahami meningkat menjadi 21 orang. Hal ini menunjukan tingkat serapan materi bagus. 


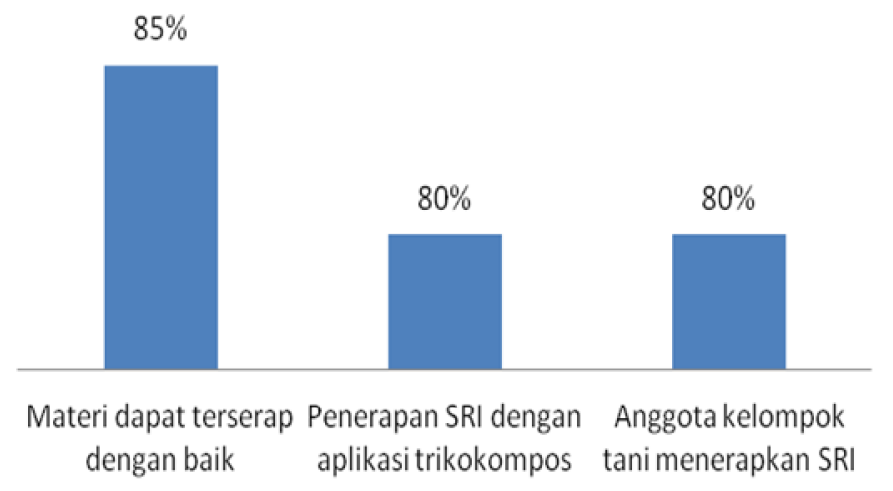

Grafik 2. Prosentasi capaian serapan materi.

Indikator capaian serapan materi budidaya SRI terserap dengan baik sebanyak $85 \%$, Penerapan SRI dengan aplikasi trichokompos $80 \%$ dan sebanyak $80 \%$ anggota kelompok tani menerapkan metode SRI dalam kegiatan usaha tani padinya. Hal ini dilihat berdasarkan musim tanam selanjutnya dalam kegiatan pendampingan berkala oleh tim pengabdi dan penyuluh lapangan sebanyak 20 orang dari 25 orang menerapkan metode SRI.

\section{Membuat Demplot Budidaya Padi dengan Metode SRI}

Pembuatan Demplot dimaksudkan agar alih teknologi dan pelatihan yang sudah diberikan kepada kelompok Tani Warakan dapat langsung di praktekkan. Demplot dilaksanakan pada lahan seluas $5000 \mathrm{~m}^{2}$. Bersebelahan dengan lahan kelompok tani lain yang melaksanakan budidaya padi secara konvensional. Diharapkan kondisi tersebut akan memberikan gambaran dan perbandingan teknik budidaya sehingga kelompok tani dan masyarakat umum dapat membandingkan kelebihan dari metode SRI dengan budidaya padi konvensional. Kegiatan pembuatan demplot dimulai dengan beberapa tahapan sebagai berikut:

\section{a. Persemaian bibit}

Sebelum dilakukan penyemaian terlebih dulu gabah/benih disortasi dengan cara direndam dalam larutan garam, gabah yang mengambang berarti memiliki kualitas yang jelek, dibuang dan gabah yang tenggelam dalam larutan air garam mempunyai mutu dan kemampuan berkecambah bagus, maka itu yang digunakan sebagai benih, pada budidaya metode SRI digunakan bibit muda umur semai 81-15 hari. Penanaman bibit muda diharapkan agar bibit dapat tumbuh dan membentuk anakan/rumpun baru dengan baik. Daya adaptasi bibit muda terhadap media tumbuh baru lebih baik daripada umur bibit tua. Perakaran bibit muda juga dapat berkembang dan menjangkau sumber hara lebih luas. berikut ditampilkan gambar sortasi gabah dan cara penyemaian. 

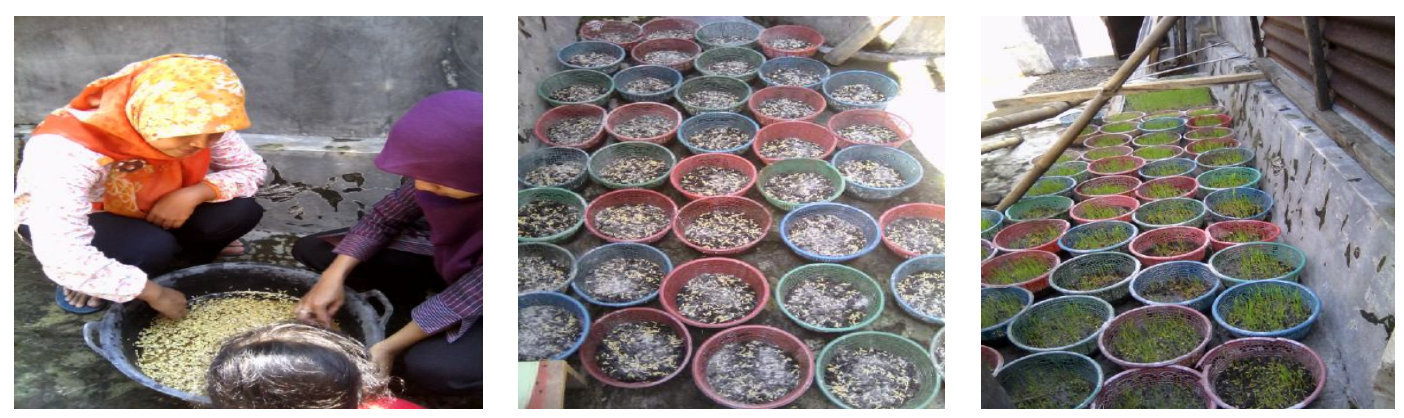

Gambar 4. Sortasi benih padi

Gambar 5.Persemaian benih

Gambar 6. Bibit padi umur 7 hss (hari setelah semai)

\section{b. Meningkatkan aerasi tanah dengan pembajakan mekanis}

Pengolahan lahan untuk penanaman padi sawah dilakukan bersamaan ketika benih mulai disemai agar waktunya sesuai, setelah selesai pengolahan dengan mulai tumbuhnya bibit dan cukup umur untuk ditanam. Pengolahan tanah dilakukan dengan cara dibajak dan dicangkul. Biasanya dilakukan minimal 2 kali pembajakan yaitu pembajakan kasar dan pembajakan halus yang diikuti dengan pencangkulan. Total pengolahan lahan ini bisa mencapai 2-3 hari. Setelah selasai, aliri dan rendam dengan air lahan sawah tersebut selama 1 hari. Usahakan bibit yang disemai tidak melebihi umur 12 hari mengingat jika terlalu tua maka tanaman akan sulit beradaptasi dan tumbuh ditempat baru (sawah) karena akarnya sudah terlalu besar.
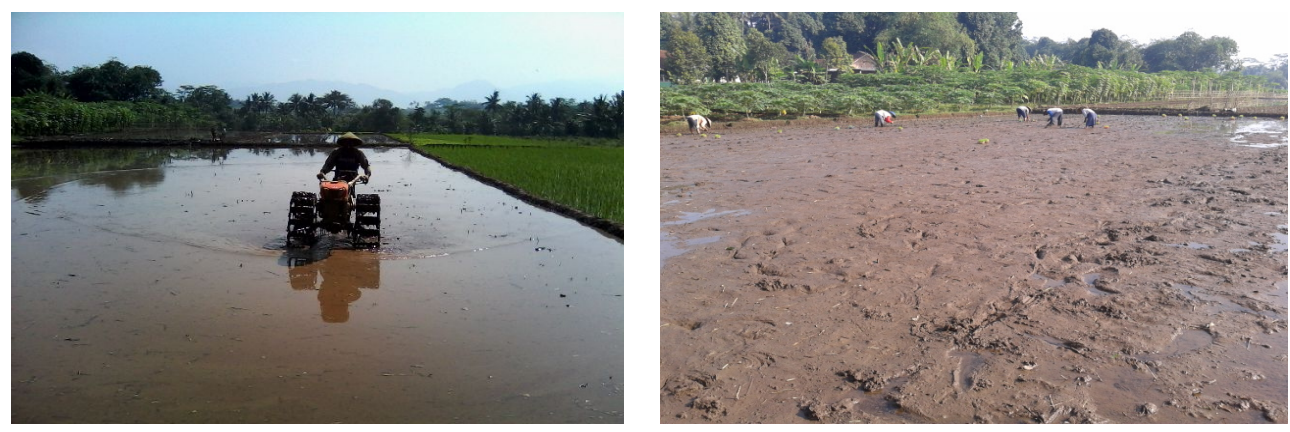

Gambar 7. Pengolahan lahan dengan bajak dan penyiapan petak demplot

\section{c. Penanaman bibit muda (8-12 hari setelah berkecambah)}

Pada percobaan demplot ini dilakukan ketika bibit berumur 12 hari setelah semai yaitu tanggal 24 Mei 2015. Maksud dari penanaman bibit muda adalah jik petani menanam bibit yang lebih tua 3, 4, 5 atau 6 minggu, maka mereka telah kehilangan banyak potensi untuk menghasilkan sejumlah anakan tanaman., Hasil penelitian Masdar et al., (2006) menunjukkan bahwa pemindahan bibit ke lapangan umur 7 hari setelah semai dapat jumlah anakan tanaman padi dapat mencapai 20,796 anakan, sedangkan pemindahan bibit umur 21 hari setelah semai jumlah anakan hanya 17,172 anakan. Penundaan umur pemindahan bibit ke lapangan 
mengakibatkan bibit mengalami stres karena terganggangunya sistem perakaran dan juga perlu waktu untuk masa penyembuhan bibit sehingga perkembanga anakan juga akan terlambat. berikut ini adalah gambar penanaman bibit muda.
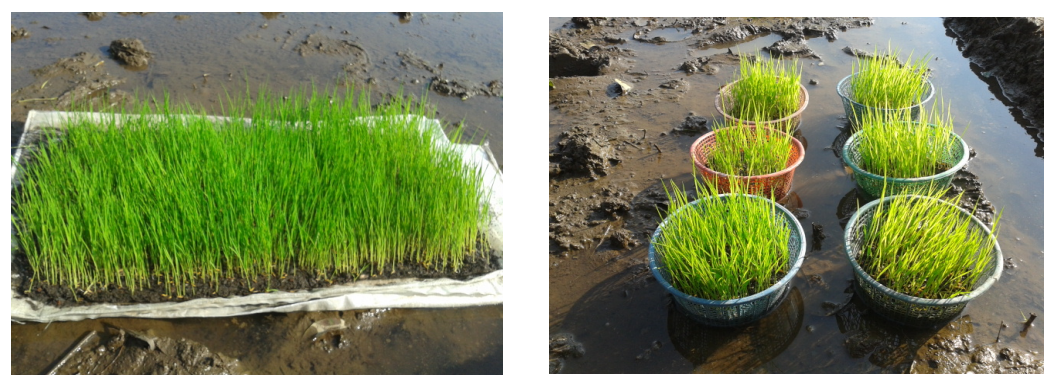

Gambar 8. Bibit padi umur 12 hss siap dipindah tanam ke lahan

\section{d. Jarak tanam yang lebar (minimal $30 \mathrm{~cm} \times 30 \mathrm{~cm}, 1$ bibit per titik)}

Jarak tanam yang lebar dimaksudkan agar bibit mendapat ruang yang cukup, tidak terlalu berkompetisi atas kebutuhan hara dan cahaya matahari dengan bibit lain karena ruang tumbuhnya cukup luas untuk tumbuh menghasilkan anakan yang banyak. Jumlah anakan dalam lubang tanam cukup 1 bibit karena lebih efisien dalam pertumbuhan jumlah anakan juga menghemat bibit.

Penanaman padi secara konvensional menggunakan jarak tanam $25 \times 25 \mathrm{~cm}$, budidaya Sistem SRI berbeda dari sistem konvensional yang sering digunakan oleh petani. Bedanya dapat dilihat dari sistem penanaman, penggunaan pupuk maupun jarak tanamnya. Pada sistem SRI, bibit ditanam dengan jarak tanam lebar 30x30 cm hal ini dimaksudkan agar bibit padi mempunyai ruang gerak perakaran yang cukup dan mendapatkan intensitas matahari supaya maksimal dalam pembentukan anakan dan proses fotosintesis.
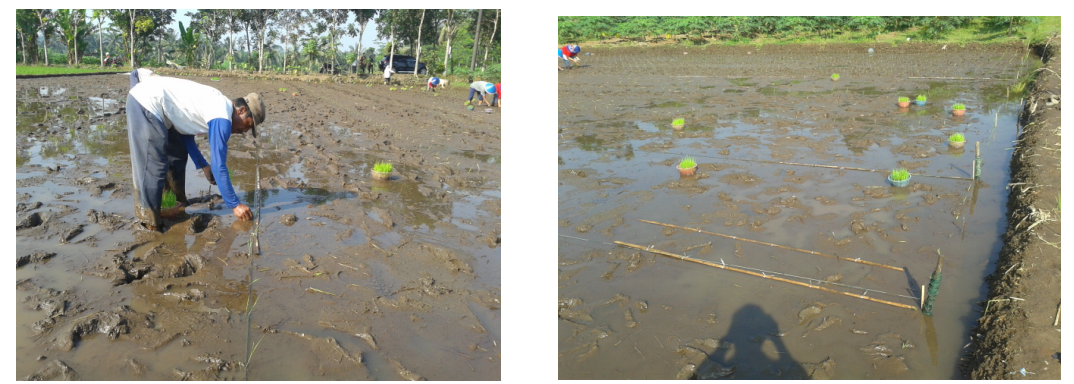

Gambar 9. Proses pindah tanam ke lahan dengan jarak tanam 30x30 cm

\section{e. Manajemen Air (Tanah dijaga terairi dengan baik, tidak terus menerus direndam dan penuh, hanya lembab)}

Pada penanaman budidaya padi organik dengan metode SRI yang paling penting adalah menjaga aliran air supaya sawah tidak tergenang terus menerus namun lebih pada pengaliran air saja. Untuk itu, setiap hari petani biasanya melakukan kontrol dan menutup serta membuka pintu air secara teratur. Berikut panduan pengairan SRI:

Penanaman dangkal, tanpa digenangi air, mecek-mecek, sampai anakan sekitar 1014 hari. Setelah itu, isi air untuk menghambat pertumbuhan rumput dan untuk pemenuhan kebutuhan air dan melumpurkan tanah, digenangi sampai tanah tidak tersinari matahari,

Dinamika Journal Vol. 1 No. 3, Oktober 2019 : 40 - 51 
stelah itu dilairi air. Sekitar seminggu jika tidak ada pertumbuhan yang signifikan dilakukan pemupukan, ketika pemupukan dikeringkan dan galengan ditutup. Ketika mulai berbunga, umur 2 bulan, harus digenangi lagi, dan ketika akan panen dikeringkan Pemberian air pada sistem ini dilakukan dengan ketinggian air maksimal $2 \mathrm{~cm}$ (macakmacak). Barkelaar (2002), menyatakan bahwa kelebihan metode SRI adalah tanaman hemat air, hemat biaya, hemat waktu, hemat bibit, ramah lingkungan, dan produksi meningkat.

\section{f. Menjaga keseimbangan biologi tanah (Penggunaan Pupuk dan Pestisida Organik)}

Pemupukan adalah faktor penting yang mempengarui produktivitas lahan dan komoditas yang dibudidayakan. Pupuk dasar yang digunakan adalah pupuk trikokompos dan pupuk kandang sekitar 10 ton/ha. Jerami padi merupakan sumber hara yang potensial dalam menambah unsur hara dan memperbaiki sifat-sifat tanah. Jerami padi mengandung $40 \% \mathrm{C}$, $0,6 \% \mathrm{~N}, 0,1 \% \mathrm{~S}, 1,5 \% \mathrm{Si}$. Dengan kandungan karbon (C) pada jerami padi yang tergolong tinggi., maka dapat diperkirakan bahwa pembakaran jerami dapat melepaskaan $\mathrm{CO} 2$ secara langsung ke udara dalam jumlah besar bila dibandingkan dengan mengembalikannya ke lahan sebagai bahan organik (Setyanto, 2008). Salah satu upaya untuk mengembalikan kesuburan tanah adalah dengan mengembalikan hara yang terkandung di jerami pasca panen karena hara yang terkandung dijerami cukup besar dan kurang dimanfaatkannya jerami setelah panen. Jerami tersebut berupa bahan organik dan kadang diberi juga pupuk kandang. Menurut Arafah dan Sirappa (2003) Penggunaan pupuk kandang dan jerami padi merupakan penggabungan pemanfaatan limbah dari peternakan dan pertanian yang dapat diterapkan sebagai pertanian organik pada pertumbuhan padi sawah yang sekaligus merupakan dasar untuk konsep pertanian organik.

Beberapa hama yang sering menyerang tanaman padi diantaranya burung, walang sangit, wereng dan penyakit ganjuran atau daun menguning. Cara penanganannya bisanya dengan cara manual, membuat orang-orangan sawah untuk hama burung, penyemprotan dengan biopstisida berbahan rimpang dan buah maja dilakukan dengan interval 20 hari sekali. Aplikasi MOL diberikan supaya tanaman padi mendapat suplai nutrisi sehingga memiliki ketahanan terhadap serangan hama penyakit

\section{g. Panen}

Panen dilaksanakan pada tanggal 29 Agustus 2015 pada saat tanaman berumur 110 hst. Kegiatan panen pada kelompok tani Warakan Tani menjadi hal yang sangat istimewa karena biasanya mengundang aparat Desa dan Petugas Kecamatan. Upaya ini dilakukan untuk menginformasikan kepada khalayak masyarakat luas mengenai kegiatan bertani dengan metode SRI. Untuk luasan Long 80 atau setara dengan $5600 \mathrm{~m}^{2}$ hasil padi organik yang didapatkan sekitar 3,2 ton GKP (gabah kering panen) atau setara dengan 6 ton/ha. Untuk kegiatan budidaya padi organik hasil tersebut menunjukkan produktivitas yang cukup bagus. Biaya produksi yang dikeluarkan tidak begitu tinggi dibandingkan dengan budidaya padi secara konvensional, hasil panen yang didapatkan lebih sehat sehingga nilai jual dari komoditas padi organik lebih tinggi daripada padi non organik. Harapannya adalah dengan diadakannya kegiatan pengabdian kepada masyarakat berbasis riset ini adalah mampu meningkatkan ketrampilan anggota kelompok tani dalam memanfaatkan sumberdaya lokal seperti mikroba dan urine kelinci sebagai biofertilizer, sehingga mampu meningkatkan produktivitas padi organik yang di budidayakan dan meningkat pula tingkat pendapatan kelompok tani. enelitian yang telah dilakukan oleh Rakhmi (2008) menjelaskan bahwa pelaksanaan metode SRI yang dilakukan oleh kelompok tani Binuang Saiyo telah sukses melakukan usahatani padi sawah dengan sistem SRI. Penelitian lain mengenai penerapan metode SRI yang dilakukan oleh Richardson (2010) di Jawa Timur menyatakan bahwa 
metode SRI yang diterapkan mampu menghasilkan panen rata-rata sebesar 7 - 8 ton/ha. Sedangkan biasanya jumlah hasil panen hanya mencapai 3 ton/ha.
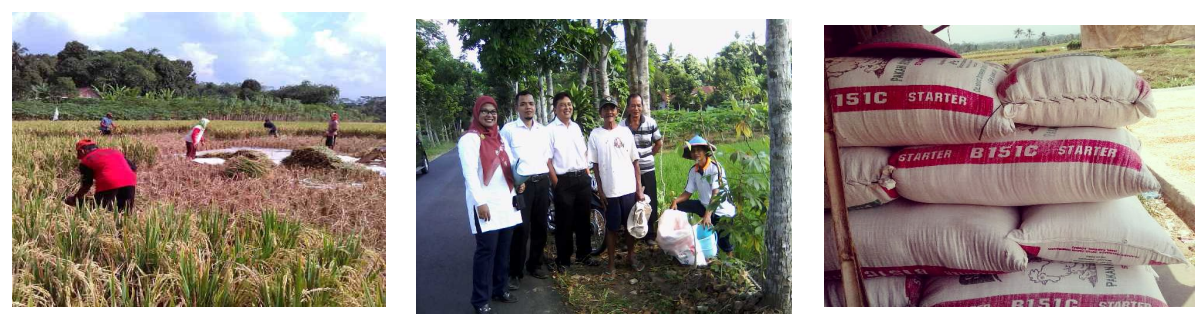

Gambar 14-16 Proses panen didampingi oleh tim pengabdi.

\section{Monitoring dan Keberlanjutan Kegiatan.}

Proses kegiatan penerapan ipteks secara umum menunjukkan hasil yang memuaskan, demplot yang dilaksanakan mampu menjawab rasa penasaran petani terkait budidaya padi Metode SRI, dari sisi biaya produksi metode SRI lebih hemat karena pemupukan dan pengendalian hama penyakit dapat dilakukan dengan memanfatakan sumberdaya yang ada disekitar lahan, penyediaan bibit juga lebih sedikit dan penggunaan air dapat disesuaikan sesuai kebutuhan tiap fase pertumbuhan padi. Hasil panen gabah kering juga lebuih tinggi 37\% dibandingkan sistem budidaya padi konvensional. Anggota kelompok tani "Warakan" cukup puas terhadap materi penyuluhan, praktek dan demplot yang dilaksanakan. Bahkan petani lain yang memiliki lahan bersebelahan dengan waktu tanam sama dan teknik budidaya yang berbeda juga menunjukkan ketertarikan atas penerapan ipteks yang sudah dilakukan. Respon yang bagus ini tentu saja menjadi satu modal yang kuat bagi tim pengabdi untuk terus mensosialisasikan budidaya padi Metode SRI, secara berkala tim masih melakukan pendampingan dan dibantu oleh penyuluh pertanian desa Patemon untuk terus konsistem menerapkan ipteks yang sudah diintroduksikan. Jika dengan luasan yang sama, biaya produksi budidaya dapat ditekan dan hasil panen dapat ditingkatkan maka diharapkan penerapan ipteks yang diintroduksikan ini dapat meningkatkan pendapatan kelompok tani "Warakan".Tingkat keberhasilan dari kegiatan ini dievaluasi dengan menggunakan parameter sebagai berikut:

a. Keikutsertaan dan respons petani selama kegiatan berlangsung sangat baik

b. Penambahan pengetahuan dalam teknik budi daya padi metode SRI

c. Produksi padi meningkat dibanding budidaya konvensional.

d. Keinginan petani lain di sekitar untuk mencoba menggunakan metode SRI sebagai mana yang dipakai dalam kegiatan ini.

\section{KESIMPULAN}

Budidaya SRI terbukti lebih efisien dalam penggunaan bibit, pupuk, air dan pengendalian hama penyakit tanaman padi. Hasil panen $37 \%$ lebih banyak dibandingkan budidaya padi secara konvensional. Kegiatan Pendampingan Penerapan Ipteks yang dilaksanakan di desa Patemon Kecamatan Bojongsari Kabupaten Purbalingga mendapat respon yang bagus dari Kelompok Tani Warakan dukungan penuh dari Kepala Desa dan Masyarakat. 


\section{UCAPAN TERIMA KASIH}

Penulis mengucapkan terimakasih kepada LPPM Universitas Jenderal Soedirman atas hibah pendanaan pengabdian masyarakat skim penerapan ipteks tahun anggaran 2015 dan dukungan perangkat Desa Patemon sehingga kegiatan pendampingan terhadap mitra sampai dengan penulisan artikel ini dapat berjalan dengan lancar.

\section{DAFTAR PUSTAKA}

Arafah dan M.P Sirappa. 2003. Kajian Penggunaan Jerami dan Pupuk N, P, dan K Pada Lahan Sawah Irigasi. Jurnal Ilmu Tanah dan Lingkungan Vol 4 (1) pp 15-24.

Barkelaar, D. (2001). Sistem Intensifikasi Padi (The Sistem of Rice Intensificaton - SRI): Sedikit Dapat Memberkan Lebih Banyak. Bulletin ECHO (Terjemahan)

Departemen Pertanian. 2008. Panduan Sekolah Lapangan Pengelolaan Tanaman Terpadu (SL-PTT) Padi, Jakarta

Handono, S.Y. 2013. Hambatan Dan Tantangan Penerapan Padi Metode SRI (System of Rice Intensification). J. Habitat . Vol.XXIV No. 1

Kuswara. 2003. Dasar Gagasan dan Praktek Tanam Padi Metode SRI (System Rice Intensification) - Pertanian Ekologis. Yayasan FIELD Indonesia.

Masdar, Musliar K., Bujang R., Nurhajati H., dan Helmi. 2006. Tingkat Hasil dan Komponen Hasil Sistem Intensifikasi Padi (SRI) Tanpa Pupuk Organik di Daerah Curah Hujan Tinggi. Jurnal Ilmu Pertanian, Vol 8 (2). 126-131.

Neni M, Eko Adi S, Nurbaiti A. 2012. Respons Tanaman Padi (Oryza sativa L.) terhadap Takaran Pupuk Organik Plus dan Jenis Pestisida Organik dengan System of Rice Intensification (SRI) di Lahan Pasang Surut. Jurnal Lahan Suboptimal, 1(2) Oktober 2012

Rakhmi F. 2008. Analysis of rice farming of System of Rice Intensification (SRI) in the group independently (Analisis Usahatani Padi Sawah SRI (System of Rice Intensification) Pada Kelompok Secara Swadaya). Fakultas Pertanian. Universitas Andalas. Padang.

Rahman, B., I.W,. Rusastra, Y. Yusdja., A. R Nurmanaf, Ashari , H. Tarigan, E. Arianingsih dan Sunarsih. 2009. Kinerja dan Dampak Strategis Departemen Pertanian. Laporan Hasil Akhir Penelitian. Pusat Analisis Sosial Ekonomi dan Kebijakan Pertanian. Badan Penelitian dan Pengembangan Pertanian

Rialisasi, H. 2013. Laporan Tahunan Kegiatan Pembinaan THL-PPL Kecamatan Bojongsari. BKP Purbalingga

Richardson MN. 2010. One of the Investigation of System Rice Intensification (SRI) in East Java (Salah Satu Penyelidikan Mengenai Keadaan System Rice Intensification (SRI) di Jawa Timur). Australian Consortium for In-Country Indonesian Studies (ACICIS). Fakultas Ilmu Sosial dan Ilmu Politik. Universitas Muhammadiyah. Malang.

Sato, S., and N. Uphoff. 2007. A review of on-farm evaluations of system of rice intensification methods in Eastern Indonesia. Perspectives in Agriculture, Veterinary Science, Nutrition and Natural Resources 54:1-12.

Setyanto, P. 2008. Perlu Inovasi Teknologi Mengurangi Emisi Gas Rumah Kaca dari Lahan Pertanian Balingtan, badan Litban Pertanian, Deptan. 
Uphoff, N., S. Rafalaby and J. R. Drasana. 2002. System of Rice Intensification. Cornell University.

Wardana, P, I. Juliardi, Sumedi, Iwan Setiajie. 2005. Kajian Perkembangan System Of Rice Intensification (SRI) di Indonesia. Kerjasama Yayasan Padi Indonesia dengan Badan Litbang Pertanian. Jakarta. 